\title{
APPROPRIACY OF PROCESS APPROACH IN THE TEACHING OF COMPOSITION WRITING IN UPPER PRIMARY CLASSES IN KENYA
}

\author{
Sophie Ahono Maninji \\ $\mathrm{PhD}$ student, \\ Department of Educational Communication, \\ Technology and Curriculum Studies,Maseno University, \\ Kisumu, Maseno, \\ Kenya.
}

Article DOI URL: $\underline{\text { https://doi.org/10.36713/epra6656 }}$

DOI NO: 10.36713/epra6656

\begin{abstract}
Imaginative composition writing skills (IMW) in Kenyan primary schools strengthen learners' learning, thinking and reflect on their overall academic performance. However, achieving good composition writing is challenging especially to non-native learners of English because of its complexity and nature. Some factors attributed to learners' writing difficulties are: the curriculum, the pedagogic approach used and teachers' lack of ability in writing instruction. These factors are in tandem with the ICW status in Vihiga County where over (70\%) of Class 8 learners' composition score are unsatisfactory, $60 \%$ of teachers are uncomfortable to teach ICW while $75 \%$ of learners find it boring. To address these ICW difficulties, this study assessed the process approach out of the three principal writing approaches because it's seen as the best alternative to product approach and that genre approach is considered a newcomer. The objective of the study was to assess the effectiveness of process approach in developing composition writing. Archer's theory of reflexivity guided the study which used qualitative exploratory research design and was conducted in Vihiga County. Data collection tools were Lesson Observation and Interview Schedules. Validity and reliability were tested through triangulation and thick description. From Class 6-8, 30 lessons in 10 purposively selected schools were observed and 30 teachers interviewed. Data were analyzed thematically through transcription, coding and identification of themes. The key finding was: ineffective utilisation of the process approach due to teachers' knowledge gaps on the approach. The study recommended teachers to use process approach effectively in ICW and the Ministry of Education to in-service teachers on writing approaches.
\end{abstract}

KEY WORDS: Process Approaches, Composition Writing, Pedagogy, in-service, and Upper Primary Learners

\section{INTRODUCTION}

Writing is the most important language skill that students require for their personal development and academic success (Mukulu et al. 2006). It strengthens learners' learning, thinking and reflects on their academic performance besides enabling learners to be professionals and researchers in the future (Ahmed, 2010; Rao, 2007; 2018). Ahmed (2010) further notes that competence in writing helps students perform well in all their academic programmes. In Kenyan primary schools, writing skills are evaluated through
Imaginative Composition Writing (ICW) which is conceptualized as the use of written language to explore and record experiences in such a way as to create a unique symbolization of it (Khan, 2011; Ochako, 2018). However, achieving good composition skills is a complex and difficult task for both native and non-native speakers of English (Cheung, 2016) because it demands a grammatically, lexically and syntactically correct and well organized composition (Schoonen, R., Van Gelderen, A., Stoel, R., Hulstijn, J., \& De Glopper, 2011). This task is even more complex and demanding 
for Kenyan learners because English is taught as a Second Language (L2). With over $60 \%$ of learners lacking basic writing skills by the end of their primary course in Kenya and over (70\%) of Class 8 learners scoring below the average mean mark, $60 \%$ of teachers finding it difficult to teach ICW while $75 \%$ of learners perceiving it boring in Vihiga County, there is need to address these Composition Writing difficulties and bring its pedagogy into perspective by assessing pedagogic approaches employed by the teachers since approaches affect pedagogical outcomes in any field and have measurable effects on the quality of the learners' written products Sengupta (2000). Research links the problems students face in composition writing to lack of motivation among students and teachers' use of traditional approaches which are frequently indifferent to learners' needs (Al-Khasawneh, 2009). Moreover, Eliwarti and Maroof (2014) conclude that L2 learners' problem in ICW skills can be caused by several factors: the curriculum, the approach used by teachers in writing instruction, and the teachers' lack of ability in writing instruction. These assertions suggest the need for a new pedagogy through appropriate approaches because lack of suitable learning approaches in writing result in low motivation and achievement for learners (Lo \& Hyland, 2007). Moreover, there have been paradigm shifts in approaches to teaching writing over the last few decades (Paltridge, Harbon, Hirsh, Shen, Stevenson, Phakiti, \& Woodrow, 2009). The three principal writing approaches are: the product approach, the process approach and the genre approach (Ibrahim, 2013). Many of the studies conducted on the utilisation of writing approaches were conducted in Western socio-cultural environment with different pedagogical contexts thus; some of the approaches require adaptation to Kenyan contextual realities for effective utilisation. In addition, English language teachers are usually trained in Western approaches and methods of language teaching, some of which need adaptation to the (L2) classes (Ong'ondo, 2009). Few studies have been conducted on $\mathrm{CW}$ in Vihiga County primary schools. No study has focused on process approaches and its effectiveness in the development of $\mathrm{CW}$ skills in upper primary classes. This paper focused on the process approach because it was seen as the best alternative to product approach which has dominated L2 classrooms and learning materials for decades (Tribble (2009) with no significant improvement in learners' composition writing skills (KNEC,2015) and the fact that genre approach is still considered a newcomer (Ibrahim, 2013). Moreover, it is believed that the process approach to writing is especially effective for learners of English as L2 (What Works
Clearinghouse, 2012; Gillespie and Graham, 2010; Andrews et al, 2009; Santangelo and Olinghouse, 2009). It also lends itself to the student-centred learning supported by the communicative approach to the teaching of English as recommended in the Botswana junior secondary education syllabus (Republic of Botswana, 2008). Besides, modern understanding now views writing as a process and the process approach was developed by way of reaction to the confines of the product approach (Tribble, 2009). In composition writing, children need to experience the writing and composing of their own texts which was alien to earlier approaches but embedded in process approach (Cox, 2003). Again, process approach empowers learners by enabling them to make decisions about the direction of their writing through discussions, tasks, drafting, feedback and informed choices (Tribble, 2009), thus encouraging them to make improvements themselves. Process approach was therefore seen as a solution to upper primary learners' unsatisfactory imaginative composition writing skills.

\section{IMAGINATIVE COMPOSITION WRITING PEDAGOGY}

It is pertinent to know that 'writing is not an innate natural ability but is a cognitive ability' (Harris, 1993 , p. 78) and has to be acquired through years of training or schooling. Teaching writing is done actively and explicitly in a developmental sequence. We can use multi-sensory teaching to incorporate all the senses in a fun and engaging way, ensuring that all children learn regardless of learning style or background (Smith, 2015). In developmental sequence, we teach the easiest skills first, and then build on prior knowledge. The teaching sequence takes advantage of child development and brain research to promote effective learning and good habits hence the need to trace how composition writing is progressively developed in upper primary classrooms (class 6-8).

Children learn in stages; imitation (The child watches as the teacher writes and then imitates the teacher).According to Gordon (2007), - Second language literacy experts recommend that literacy instruction should start early in the ESL classroom, before children develop full proficiency in a second language (p. 96). In primary schools, EFL pupils progress from writing isolated words and phrases, to short paragraphs about themselves or about very familiar topics (family, home, hobbies, friends, food, etc.) From the preceding assertions, it is important to note that many pupils at primary school level are not yet capable either linguistically or intellectually of creating a piece of written text on their own, it is important that time be spent building up the language 
they will need using process approach on which they can then base their own efforts.

Archibald (2001) also observes that teaching has an effect on the students' ability to reflect on their writing and to produce more effective and appropriate texts in L2 language. Teaching imaginative composition writing using the correct approaches therefore gives rise to appropriate compositions. On the other hand, Myles (2002) observes that the ability to write well is not naturally acquired from the environment through exposure to the language. He argues that writing is learned or culturally transmitted as a set of practices in formal instructional setting. These practices are embedded in the various approaches of teaching writing; key among them, the process writing approach. The teacher therefore ought to choose and adopt process approach to imaginative writing based on the aspect being taught. This is because every stage of the approach has its advantages and limitations. For example, the advantage of the process approach is that it enhances organization-the right flow and sequence of events while its limitation is in seeing the writing process as a linear sequence which practically, it is not so.

Similarly, Byrne (2000) notes that writing is learned through a process of instruction in which the student is expected to master the written form of the language and to learn certain structures that are not common in speech but which are vital for effective written communication. He further observes that conscious effort must be made to equip language learners with writing skills which will enable them to organize their ideas so that a reader who is not present and even known to them can understand. In support of this observation is Mustafa (2009) who believes that if imaginative writing is taught effectively, it can provide learners with an opportunity for skill building, communication and expression.

In addition, Tangpermpoon (2008) asserts that teaching writing skills to L2 students is a challenging task for teachers because developing this skill takes a long time to realize the improvement. It was therefore in the interest of this study to establish the teaching of imaginative writing progressively in the primary upper classes (6-8), the pedagogic approaches teachers employ in imaginative writing classrooms based and factors that determine the choice of a particular approach against other approaches and the effectiveness of the approaches in helping learners produce well crafted imaginative compositions.

imaginative writing relies on the preparedness of teachers to teach creative writing (Milton, Rohl \& House, 2007; Reid, 2009; Thompson, 2010; Blake \&
Shortis, 2010); a preparedness which many classroom teachers may/do not have; and that there exists an ongoing debate as to whether or not imaginative writing is actually teachable (O'Reilly, 2011; Wandor, 2012; Donnelly, 2012; Morley \& Neilsen, 2012; Harper, 2013). This ongoing debate connotes the difficulty and challenges of imaginative writing pedagogy. Richard (2008) argues that from a pedagogical point of view, techniques for improving writing will include practice in writing by the very teachers who are teaching it. In other words, teachers will need to be seasoned writers in themselves, not only of literary and fictional genres but in informational and argumentative genres too. They will not only be able to produce final products in this range of genres but also to reflect on and model the processes of writing in the classroom. (p.14). This sounds right but it also sounds fairly daunting, especially if you are a primary school teacher expected to cover a wide number of subject areas.

\section{THE PROCESS WRITING APPROACH}

Utilization of appropriate writing approach results in good, well written, coherent and balanced compositions (Adas \& Bakir, 2013). Teaching writing has seen numerous approaches and methods crossing its way since the early eighties. The focus has shifted from sentence structure and grammar drills to usage and text organization as argued by Richards (2005) that from the beginning of the $19^{\text {th }}$ century, different language teaching approaches have been applied and that teachers and linguists have periodically sought to improve language teaching methods. As a result of different changes in viewpoints toward writing practice and its important role for second language learning, various pedagogical approaches have been proposed by different researchers (Matsuda, 2003). Among the approaches proposed, Eliwarti and Maarof (2014) argue that process approach is one of the three popular and holistic approaches that encompass aspects of accuracy, fluency and creativity. Fluency, accuracy and creativity form the three broader scoring areas in imaginative compositions for the Kenyan upper primary learner.

Rao (2018) citing Graham (1993) postulates that the process approach treats all writing as a creative act which requires time and positive feedback to be done well. In process writing, the teacher moves away from being someone who sets learners a writing topic and receives the finished product for correction without any intervention in the writing process itself. "Process Approach stresses writing activities which move learners from the generation of ideas and the collection of data through to the publication of a finished text." 
Critically looking at the above definitions, (Rao, 2018) teases out key points that Process approach advance in developing learners writing skills. It is learner-centered in which learners' needs, expectations, goals, learning styles, skills and knowledge are taken into consideration. It takes time to develop the skills.

Relating these arguments with the workload and time allocation for Kenyan Primary school English lessons (35 minutes), there need for a review of time allocation because as it is, it limits the collaborative nature the process approach should adopt. The students work in groups and these groups become collaborative teams. The peer or shared writing encourages students to reflect on all aspects of writing (Tufail, 2013). Such activities make imaginative composition writing interesting and captivating. The teacher is a facilitator (Elbow and Belanoff, 2000) and extends the writing abilities of the pupils by suggesting how to improve the content, organization and vocabulary in writing (Tufail, 2013). The teacher in the process writing approach is concerned with the students' needs and intervenes with the help when the need arises. Focusing on imaginative writing which requires original, creative and symbolic use of language, the process approach has been considered appropriate because it treats all writing as a creative act which requires time and positive feedback to be done well (Graham and Gilbert, 2015). Moreover, in the process approach to imaginative writing, the teacher is involved in the writing process itself and gives feedback during the writing process, thus encouraging an improvement in imaginative writing among learners unlike when learners have to emulate models in the product approach thus stifling creativity. Therefore, every stage of the writing process should be studied and demonstrated by teachers and students in order to develop the writing abilities (Tufail, 2013).

Considering factors that influence the different types of writing activity, Badger and White (2000) argue that the disadvantages of process approaches is the production of all writing by the same set of processes, giving less importance to the kind of texts writers produce and why such texts are produced, and offer learners insufficient input particularly about linguistic knowledge to write successfully. However, with the stages of writing in process approach, the learner is not expected to write on a given topic in a restricted time, and wait for the teacher to correct their paper but rather writing a first draft, shows it to the teacher or to another student, reads it again, enriches it, and revises it before writing the final draft, upper primary teachers can utilize it to help the learner generate a story through peer learning.

\section{RESEARCH METHODOLOGY}

The objective of the present study was fulfilled through a qualitative exploratory research design which, according to Burns and Groove (2001), is conducted to gain new insights, discover new ideas, and for increasing knowledge of the phenomenon. The study explored the process approach upper primary teachers employ during their writing lessons in order to gain insights into the effectiveness of this approach in imaginative composition writing instruction and suggested ways of improving the same in Vihiga County primary schools. The study was carried out in Vihiga County in the Western Region of Kenya. The choice of Vihiga County was influenced by the fact that the public primary schools in this area have persistently underperformed in English composition and also its rural setup that can exemplify practice as opposed to the urban setups which are well resourced and are deemed to have L2 competent learners. Stratified purposive sampling was employed to select teachers of English from the purposively selected schools from class 6,7 and 8 for lesson observation during their teaching of CW. Teachers whose lessons had been observed were interviewed by the researcher in order to help the researcher corroborate the data that had been collected. Stratified purposive technique was appropriate for the present study because it focuses on characteristics of particular subgroups of interest. The sample was stratified based on the level of upper primary classes hence the Class 6,7 and 8 that were involved in the study.

All the 30 teachers of English from the 10 purposively selected schools were interviewed and 30 imaginative composition lessons; one from each class in the 10 selected schools was observed during instruction. The 30 teachers interviewed and the 30 lessons observed were informed by Guest, Bunce, and Johnson (2006) who advocate for saturation, the point at which a researcher no longer receives any new information or insight into the phenomenon of study from each subsequent interview or observation, and it often occurs at around 12 for a homogeneous participant group. They further argue that a minimum of 15 for most qualitative interview studies works very well when the participants are homogeneous. In this study, homogeneity of participants involved teachers of English in upper primary classes for interview and observation of upper primary $\mathrm{CW}$ lessons. For a particular group, saturation often occurs between 12 and 15. However, Nastasi (2005) recommends a sample size of 30 for in-depth interview thus the interviewing of the 30 teachers of English in upper primary classes. Oral semi structured interview schedules were administered to class 6,7 and 8 teachers of English on 
the process approach and its effectiveness in developing CW skills because interview schedules are a feasible and adaptable way of finding out information (Cresswell, 2009). For classroom observation, according to Wragg (2011), they are used in a study and should suit its purposes. Therefore, the classroom observation methods and procedures were carried out in line with the research's main purpose of establishing hoe effective the approach was and current composition writing practice in Kenyan upper primary classrooms.

Stake (2005) explains that to give quality, credibility, and trustworthiness to a qualitative research, certain methods are used which include: triangulation, saturation, member checking and selfdisclosure (Reflexivity). In qualitative research, validity entails the researcher checking for the accuracy of the findings by employing certain procedures, while reliability indicates that the researcher's approach is consistent (Creswell, 2009). To ensure that the findings in this research are accurate and credible, a number of measures were taken. Validity strategies such as data triangulation and the use of thick and rich descriptions of the procedures and findings were used. By converging data from the two sources, conclusions were drawn from various angles making the research findings trustworthy. Secondly, the researcher involved peers and experienced researchers in reviewing key concepts, methodology and analysis and to help check the credibility of the research rationale, research process and report as suggested in research literature (Stake, 2006).

Regarding reliability, Richards (2009) explains that "dependability in qualitative research involves an interrogation of the context and the methods used to derive the data" (p159). Yin (2003) suggests that one way of enhancing dependability is to make clear and detailed descriptions of the steps followed in the study. To ensure dependability in this study, care was taken to make a thick description of the entire research process in a manner that makes it possible to carry out a similar study in another context, if necessary (Ponterotto, 2006). In the process of data generation, the researcher accumulated a data set consisting of interview and observation notes. The researcher utilized thematic analysis. Braun and Clarke (2006) explain that: Thematic analysis is a method for identifying, analysing, and reporting patterns (themes) within data. It minimally organizes and describes your data set in (rich) detail. To ensure consistency in approach during the study, the exploratory study procedures was documented and applied consistently in the data collection phase by immediately describing in detail the opinions and feelings and the behavior captured during interviews and classroom interactions; then transcribing the data. The same procedure was used for all the ten classroom observations. Once classroom observation data was transcribed from recorded classroom interactions and checked for accuracy to make sure that it does not contain mistakes. Measures were also taken in thematically coding to ensure that there were no drifts in the definitions of codes or shifts in the meaning of codes during the process of coding.

Data analysis was achieved using content and thematic analysis and discourse analysis. Interview data was subjected to narrative while classroom observation data was analysed using discourse analysis. Teacherlearner interactions from the classroom observation were used to corroborate the data from the interviews with teachers about the methods they employ to teach $\mathrm{CW}$. Narrative approach was used to present data from teacher interviews. In terms of ethics, according to Mason (2002), the researcher observed truthfulness and all participants were given accurate and detailed information about the research, their express consent, confidentiality and anonymity were assured, any sort of harm was avoided and the researcher show appreciation of the participants' support in any appropriate manner (Cohen et al., 2007). The researcher then wrote a detailed report using qualitative data that was thematically interpreted and described in subsection under the process approach in focus.

\section{RESULTS AND DISCUSSIONS}

The analysis of results was from Class 6 to 8. In Class 6 process oriented approach, the teacher was not clear on the aspects of composition writing the teacher intended to develop though process writing. The aspects witnessed were the generation of ideas through questions such as 'who', 'where' and 'when' of the events in the story and an attempt for learners to work together through discussions on the relevant vocabularies to be infused in a story. This contravenes Tufail (2013) postulation that every stage of the writing process should be studied and demonstrated by teachers and students in order to develop the writing abilities. Groanwegan (2008) and Durga and Rao (2018) validate this attempt by arguing that in the process approach, learners are encouraged in their pairs or groups to freely exchange ideas and opinions concerning the information structure, language, supporting arguments among others while the teacher's role is to facilitate and provide guidance whenever it is needed. The teacher's role in the Class 6 lessons observed was inadequate since most of the time; the teacher dominated the lesson with little collaboration encouraged.

The other aspect of process writing approach that came out was the editing of work where learners 
were encouraged to go through their work and correct the mistakes they could have made. Again, this aspect failed to meet the process writing approach threshold where there ought to be peer editing or the teacher guiding the learners through the editing process (Tribble, 2009)

In Class 7 process approach lessons, learners exhibited difficulties in answering the questions raised by the teacher. The teacher alluded to the process approach right from the beginning of the lesson development. She clearly talked about generation of ideas and following steps of writing. She indicated how to generate ideas using the football match through the $4 \mathrm{~W}$ and the $\mathrm{H}$ questions. In terms of creativity, she asked the learner on how to create interest in the composition but there was no response, an indicator that learners struggle to infuse creativity in their compositions. The teacher also talked about other aspects of process approach like writing an outline of the story. Other aspects that were mentioned but not expounded on include: the introduction of conflict in the story (turns and twists), use of phrasal verbs (vocabulary), proverbs, exclamations and the mention of mechanical aspects of a good composition like hand writing and appropriate length. The picture depicted by these presentations was either the assumption by the teachers that the learners were aware of the aspects of a good creatively written text or the inadequacy of the teacher to handle the same.

In Class 8 , the teacher alluded to the process approach aspect of planning through the $4 \mathrm{~W}$ and $\mathrm{H}$ questions. The central focus was on the steps that make up the act of writing. This made the teacher capture generation and organization of the ideas while the rest of the stages like, drafting, revising, and publishing were not utilized. In the introduction, the teacher was keen on the aspect of writing creatively in order to make the story interesting but coming to lesson development, these teachers helped learners how to generate the ideas to write, a key aspect of process approach to writing that dominated the lesson.

The other two aspects of process writing that were utilised in the lesson were discussions and the need for learners to edit their work. Learners were also reminded of good mechanics of a good composition, however, in this instance; the teacher did not delve fully into the mechanics in order to help the learner grasp what is expected in creating an interesting story. The teacher only mentioned the need to write in prose, and making the story interesting using appropriate vocabulary, proverbs and similes.

Class 6 to 8 process approach lessons revealed that teachers adopted only a few aspects of the process writing approach. These were: brainstorming and organization of the information, collaborative learning and editing; which again were not fully utilized as the approach demands. Brainstorming and organization of the information was very helpful as it ensured learners had what to write (content) and in an orderly way. However, good writers plan and revise, rearrange and delete text, re-reading and producing multiple drafts before they produce their finished document and this is what a process writing approach is about (Stanley 2003).

To gain insight into the fragmented utulisation of the approach by the teachers, the researcher through interviews with the teachers whose lessons had been observed asked the teachers to describe how they approached and taught imaginative compositions. The descriptions from teacher interviews revealed a lack of full knowledge and understanding of the process approaches to writing which explains why the teachers utilized a few aspects of each of the approaches rather than utilizing the approaches fully. Samples of these descriptions from Class 6,7 and 8 teachers of English respectively were:

"I give a topic in groups of 5, learners discuss it and agree on what to write then they write individually. Time determines whether classroom discussions will be done and corrections made.'

'The 5 WH questions guide me. I give a question for each stage, explain each with Process an example, learners write, I teacher read the best composition in class and give it to low achievers.'

I do individualized instruction, and then group. Work, gives a sample composition, then learners write then teacher marks and makes correction.'

A fully and adequately utilized process approach helps the learners through various stages of composing and it involves eight consecutive stages of writing strategies that enable learners to write freely and produce texts of good quality (Durga \& Rao; 2018)which were lacking in the lessons observed. These stages are: generation of ideas by brain storming and discussion, learners extending their ideas into a note form and judge quality and usefulness of ideas, the teacher helping learners make the relationship of ideas understandable-organizing their ideas into mind map or linear form, learners preparing first draft in the classroom usually in pairs or groups, then drafts are exchanged for students' reading and responding from each other's works. In this way, students develop an awareness of the fact, considering the feedback of other students, drafts are improved with necessary changes, finally, students prepare the final draft with necessary changes and in Stage 8, the final draft is evaluated by the teachers providing a feedback on it. 
As mentioned earlier, the only item of the process approach emphasizes across the three upper primary classes was generation of a story using the 4Ws and $\mathrm{H}$ questions. Important as editing and revising are, they were equally not utilized effectively from the lessons observed. The main concern of the revising stage is to complete the content correctly, whereas correcting grammatical and spelling mistakes can be done during the editing stage (Tribble, 2009). In the revising stage learners should carry out activities such as deleting unnecessary sentences and moving certain words or paragraphs forward or backward (Williams, 2003; Hedge, 2000). All the teachers included in the study admitted they failed to guide learners through the revising stage because of time constraint thus the common phrase, "proof read your work to avoid silly mistakes."

Editing is the last stage of the process approach to writing. This stage concentrates on linguistic accuracy: grammar, spelling and punctuation (Durga \& Rao, 2018). Hewings and Curry (2003) state that the editing stage involves checking references and formatting the students' writing. In this stage students may employ various strategies to correct their mistakes, such as working in pairs or in groups, and use any available resources such as textbooks, dictionaries and computers (Hewings \& Curry, 2003). Out of the eight stages in process approach, only planning seems to be attempted in the lessons observed. However, from the preceding discussion, if these stages are followed adequately and appropriately, they will go a long way in helping upper primary learners to be good imaginative composition writers.

\section{CONCLUSIONS AND \\ RECOMMENDATIONS}

On the basis of the findings of the study, the following conclusions were made:

1. Teachers in Vihiga County rarely used process approaches effectively to teach composition due to inadequate time and inadequate knowledge in CW approaches.

2. Teachers of English should continually be in serviced on composition writing pedagogical approaches with emphasis placed on process approach.

3. Effective use of process approach can help learners gain confidence during composition writing since they know what to write and how to write. Teachers in upper primary school should therefore be encouraged to use process approach to improve the teaching of composition because it enhances creativity of thought and language use and fluency in logic and flow of ideas which are key areas in English composition.

\section{Recommendations}

1. Teachers of English should learn and embrace the effective use of process approach in the teaching of composition. This too should be adopted and standardized by the Kenya Institute of Curriculum Development and to both teachers and learners relevant ICW materials.

2. The Ministry of Education in Kenya to organize for teachers of English regular training and refresher courses on the teaching English composition writing using process approach besides the other two principal approaches, that is, product and genre approaches of writing.

3. A review of the pre-service and in-service English courses with attention directed to imaginative composition writing.

\section{REFERENCES}

1. Adas, D., \&, A. Bakir. Writing Difficulties and New Solutions: Blended learning as an Approach to Improve Writing Abilities. International Journal of Humanities and Social Science. Vol.3:254-266. (2013).

2. Ahmed, A.Students' problems with cohesion and coherence in EFL essay writing in Egypt: Different perspectives. Literacy Information and Computer Education Journal (LICEJ), Vol.1:219-221. (2010).

3. Badger, R., \& White, G. Product, process and genre: Approaches to writing in EAP [Electronic version]. ELT Journal, 54(2), 153-160. (2000).

4. Braun, V. and V. Clarke Using thematic analysis in Psychology. Qualitative Research in Psychology, 3,77-101. (2006).

5. Burns, N. \& Groves, K. The Practice of Nursing Research: Conduct, Critique \& Utilization, 261285,Elsevier Science Publishers. (2001).

6. Clarke, V. Using thematic analysis in Psychology. Qualitative Research in Psychology, 3,77-101. (2006).

7. Cohen,L. et al. Research Methods in Education( $5^{\text {th }}$ ed.). London: RoutledgeFalmer.

8. Composition Skills in the Primary School. Comprehension".TESOL Quarterly 21, 4, 737 758. (2009).

9. Cowley, S. Getting the Buggers to Write. London: Continuum. (2004).

10. Creswell, J. W. Research Design: Qualitative, Quantitative, and Mixed Methods. (2009).

11. Durga, $S$ \&. Rao, C. Developing Students' Writing Skills in English -A Process Approach ISSN: 2456- Research Gate Journal Issue 6, Vol. 2. (2018). 
12. Eliwarti, E. \& Maarof, N. The effects of types of writing approaches on EFL students' writing performance. In SELT (pp. 112-119). Padang: (2014).

13. Gathumbi, A. W. and S. C. Masembe Principles and techniques in language teaching. Nairobi: Jomo Kenyatta foundation. (2005).

14. Gathumbi, A.W \&Musembe, C.M. Principles and Techniques in Language Teaching. Nairobi: Jomo Kenyatta foundation. (2008)

15. Gillespie, A. and Graham, S. Evidence-based practices for teaching writing. Johns Hopkins University School of Education: New Horizon for learning. (2010) http://education.jhu.edu/newhorizons/Better/article s/Winter2011.html

16. Groenwegen,T. Benchmarks for English language, Education Practioners,Nairobi: Phoenix publishers. (2008)

17. Guest, G., Bunce, A., \& Johnson, L. How many interviews are enough? An experiment with data saturation and variability. Field Methods, 18(1), 24. doi: 10.1177/1525822X05279903 (2006).

18. Harmer, Jeremy. The Practice of English Language Teaching. Fourth Edition. China: Pearson, Longman. (2007).

19. Hasan, M. K. \& Akhand, M.M. Approaches to Writing in EFL/ESL Context: Balancing Product and Process in Writing Class at Tertiary Level. Journal of NELTA, 15: 77-88. (2010).

20. Hasan, M. K \& Akhand, M. M. Approaches to Writing in EFL/ESL Context: Balancing Product and Process in Writing Class at Tertiary Level. Journal of NELTA Vol. 15 No. 1-2. (2011). https://www.researchgate.net/publication/32548962 $\underline{5}$

21. Hewings, D. \& Curry, M.J. Approachec to Teaching Writing. In Coffin, C; Curry, $M$. J;Goodman, S; Hewings, A;Lillies,T. M \&Swann,J. Teaching Academic Writing; A toolkit for higher education. London. Routledge. (2003)

22. Ibrahim, I. E. The Effect of the Genre-Based Approach to Teaching Writing on the EFL Al-Azhr Secondary Students' Writing Skills and their attitudes towards writing. Unpublished PhD Thesis. Mansoura University. Mansoura. (2013).

23. Kenya National Examination Council. Report on candidates performance in Kenya certificate of secondary education. Nairobi: KNEC. (2015).

24. Khan, I. English Teachers' Perception about Creativity and Teaching Creative Writing in Pakistan. American International Journal of Contemporary Research. (2012).

25. Kim, Y., \& Kim, J. Teaching Korean University writing class: Balancing the process and the genre approach. Asian EFL Journal Quarterly, Vol.7, 6990. (2005).

26. Kioko, A. N. \& Muthwii, M. J. The Demands of a Changing Society: English in Education in Kenya
Today. Language, Culture and Curriculum, 14(3), 201-213. (2001).

27. Lipstein.L.L,; \&Renninger, K.A. Interest for Writing; How teachers make a difference. English Journal, Vol, 96,79-85. (2007).

28. Lo, J., \& Hyland, F. Enhancing students, engagement and motivation in writing: The case of primary students in Hong Kong. Journal of Second Language Writing, 16(4), 219-237. (2007).

29. Mason, J. Qualitative researching ( $\left.2^{\text {nd }} e d.\right)$. London: Sage Publications. (2002).

30. Matsuda, P. K. Process and post-process: A discursive history. Journal of Second Language. (2003).

31. Mukulu, E.,Indangasi, H., Mwangi, P., Gecaga,C. \& Okanga, N. KCSE Revision English. Nairobi.Kenya Literature Bureau. (2006.)

32. Mwangi, L. Effect of Dramatization on Learner Achievement in Learning English Language in Public Secondary Schools in Meru County, Kenya. Unpublished master's thesis, University of Nairobi, Nairobi, Kenya. (2016).

33. Nastasi, B. Contributions of Qualitative Research to the Validity of Intervention Research.Journal of School of Psychology, Vol.43:177-195. (2005).

34. Ochako, I. K., Okwako, E., \& Okoth, T. Approaches Teachers use in Teaching Imaginative Writing - a case of Secondary School Teachers in Kakamega Central Sub-County, Kenya. International Journal of Academic Research Business and Social Sciences, 9(5), 167-176. (2019).

35. Ong'ondo,C.O. Pegagogical Practice and Support of English Language Student Teacher during Practicum in KenyaPhD Thesis; University of Leeds. (2009).

36. Ponterotto, J. G. Brief note on the origins, evolution, and meaning of the qualitative research concept "thick description". The Qualitative Report 11 (3), 538-549. (2006).

37. Rao.Z. Training in brainstorming and developing writing skills. ETL Journal, 61(2), 44-51. (2007).

38. Reem, A.; Danyah,A.W.;Nadia, S. Teacher and Students' Perceptionson the Effectiveness of the Writing Tasks in the Foundation Year, King Abdulaziz University, Jeddah, KSA. (2018)

39. Richards, J. Communicative Language Teaching Today. Cambridge: Cambridge University Press. (2005).

40. Richards, J. C. Curriculum Development in Language Teaching. Cambridge: Cambridge University Press. (2009).

41. Richards, J.C Second Language Teacher Education Today. RELC Journal, Vol. 39, (2008).

42. Santangelo, T. and Olinghouse, N. Effective Writing Instruction for Students who have Writing Difficulties. Focus on exceptional children. (2009).

43. Silverman, D. Analyzing Talk and Text. In N. K. Denzin and $Y$. S. Lincoln (Eds). Collecting and interpreting qualitative materials (pp. 340-362). London: Sage Publications, Inc. (2003). 
44. Stake, R. E. Qualitative case studies. In N. K. Denzin and Y. S. Lincoln (Eds.), The Sage handbook of qualitative research (3`d ed. ), ( $p p$. 443-466). London: Sage Publications Limited. (2005).

45. Stake, R. E. Multiple Case Study Data Analysis. New York: The Guilford Press. (2006).

46. Standard Digital 'Kaimenyi's Speech on the Release of 2013 KCSE Examination Rresults', (2014) [Online Newspaper] Available at:http://www.standardmedia.co.ke/lifestyle/article/ 2000105981/kaimenyi-s-speech-on-therelease-of2013-kcse-exam-results?pageNo 2

47. Stanley, G. Approaches to Process Writing, www.teaching English.net/think/write/process_write.shtml (2007).

48. Sure, N. \& Ogechi, E. Linguistic Human Rights and Language Policy in the Kenyan Education System. Oxford, UK: African Books Collective Limited TESOL (2006). Pre-K-12 English Language Proficiency Standards, Alexandria, VA: TESOL International Association. (2009).

49. Tangpermpoon,T Integrating Approaches To Improve Students Writing Skills for English Major Students. ABAC Journal Vol. 28, No. 2 (MayAugust 2008, Pp.1-9) (2008).

50. Tribble, C. Writing. New York: Oxford University Press(2009).

51. What Works Clearinghouse Teaching elementary school students to be effective writers. (2012).

52. Williams, J. G. Providing feedback on ESL students" written assignments. The Internet TESL Journal, IX (10), 123-129 (2003).

53. Wragg, E.C. An Introduction to Classroom Observation. London: Routledge. (2011).

54. Yasuda, S. Genre-based tasks in foreign language writing: Developing writers' genre awareness, linguistic knowledge and writing competence. Journal of Second Language Writing. 20: 111-133. (2011).

55. Yin, R. K. Case study research design and methods ( $3^{\text {rd }}$ ed.), London: Sage Publications. (2003). 